To Maega | Jurnal Pengabdian Masyarakat

Agustus 2021, Vol.4, No.2, hal. 208-220

$\operatorname{ISSN}(P): 2622-6332 ; \operatorname{ISSN}(E): 2622-6340$

http://www.ojs.unanda.ac.id/index.php/tomaega

\title{
Strategi Pembelajaran di Masa Pandemi, Pada Kelompok Bermain "Flamboyan" Cokrokusuman, Yogyakarta
}

\author{
Ninik Mardiana ${ }^{1,}{ }^{*}$, Edy Widayat ${ }^{2}$, Sumartono $^{3}$ \\ 1, Pend. Bahasa Indonesia, FKIP, Universitas Dr. Soetomo Surabaya \\ ${ }^{2}$ Magister Teknologi Pendidikan, FKIP, Universitas Dr. Soetomo Surabaya \\ ${ }^{3}$ Pend. MIPA, FKIP, Universitas Dr. Soetomo Surabaya \\ *Correspondent Email: ninik.mardiana@unitomo.ac.id
}

\section{Article History:}

Received: 15-06-2021; Received in Revised: 25-06-2021; Accepted: 06-07-2021

DOI: http://dx.doi.org/10.35914/tomaega.v4i2.768

\begin{abstract}
Abstrak
Pada masa pandemi yang mengakibatkan pembelajaran harus melalui sistem PJJ (Pembelajaran Jarak Jauh), pihak KB Flamboyan membutuhkan arahan serta masukan agar pembelajaran tetap berlangsung dengan menerapkan strategi pembelajaran yang cocok. Mengingat dalam kondisi pandemi dan usia dini rentan terhadap penularan viruz, namun juga mengingat pembelajaran harus tetap berjalan, pihak mitra berharap arahan dari tim dosen dalam menyusun strategi pembelajaran jarak jauh yang cocok untuk anak usia dini. Oleh sebab itu KB "Flamboyan" bekerjasama dengan tim dosen Unitomo untuk mengadakan penyuluhan dan pelatihan strategi pembelajaran yang menyenangkan bagi pembelajaran prasekolah. Kegiatan pengabdian ini dimulai dari identifikasi KB "Flamboyan", kesepakatan penentuan objek pelatihan, pelatihan dan pendampingan, serta evaluasi bersama. Hasil yang telah dicapai adanya peningkatan keterampilan guruguru (SDM) KB "Flamboyan" dalam berkreasi membuat strategi pembelajaran yang aman dan nyaman bagi siswa, baik secara luring maupun daring dengan dalam koridor keterbatasan orang tua siswa.

Kata Kunci: strategi pembelajaran, pandemi, daring, luring
\end{abstract}

\section{Abstract}

During the pandemic, which resulted in learning having to go through the PJJ (Distance Learning) system, the KB Flamboyan team needed direction and input to keep learning going by applying appropriate learning strategies. Considering that in a pandemic condition and at an early age, they are vulnerable to virus transmission, but also considering that learning must continue, the partners hope for direction from the lecturer team in developing distance learning strategies that are suitable for early childhood. Therefore, KB "Flamboyan" collaborates with the Unitomo lecturer team to provide counseling and training on fun learning strategies for preschool learning. This service activity starts from the identification of the KB Flamboyan, an agreement to determine the object of training, training and mentoring, and evaluation. The results that have been achieved are an increase in the skills of KB "Flamboyan" teachers in creating safe and comfortable learning strategies for students, both offline and online within the corridors of the limitations of parents.

Key Word: learning strategy, pandemy, online, offline 


\section{Pendahuluan}

Berawal dari masa pandemi covid 19 yang menyerang seluruh wilayah Indonesia, mengakibatkan proses belajar mengajar di sekolah berubah menjadi belajar dari rumah atau biasa dikenal dengan pembelajar jarak jauh (Koedoes, 2020). Pemberlakuan PSBB (Pembatasan Sosial Berskala Besar) terjadi di semua lini untuk menghindari penularan yang cepat dari dan antarindividu yang disebabkan oleh pendemi covid 19. Dengan adanya PSBB ini pula, berlaku kerja dari rumah dan juga proses belajar mengajar dari rumah (Astuti, 2020). Keadaan ini tidak menyurutkan tim dosen FKIP Universitas Dr. Soetomo untuk tetap melaksanakan kegiatan Tridharma Perguruan Tinggi, yang selain mengajar, meneliti, dan juga mengadakan pengabdian pada mayarakat. Kegiatan Tridharma Perguruan Tinggi di universitas Dr. Soetomo dilaksanakan dengan cara daring (dalam jaringan) dan ada juga secara blandid yaitu perpaduan antara tatap muka dengan tatap maya, tentu saja dengan komposisi metode daring (dalam jaringan) lebih besar daripada metode tatap muka.

Keadaan PSBB ini, mengakibatkan dosen-dosen bekerja dari rumah di wilayah masing-masing. Dengan perkiraan bahwa masa pandemi berlangsung dalam waktu yang lama, beberapa dosen melaksanakan kegiatan Tridharma Perguruan Tinggi dari rumah dan kembali melaksanakan kewajiban Tridharma di wilayah masing-masing. Pihak mitra ini berlokasi dekat dengan ketua pelaksana, sehingga program pelaksanaan pengabdian masyarakat bisa berjalan dengan baik. Koordinasi dengan tim dosen yang berada di kampus Surabaya dilaksanakan dengan cara memanfaatkan media sosial dan aplikasi dalam jaringan. Pemanfaatan media sosial dan segala bentuk fasilitas maupun aplikasi dalam jaringan, untuk segala keperluan koordinasi di masa pandemi ini mutlak diperlukan. Tim dosen memutuskan pada akhirnya mitra pengabdian masyarakat untuk semester gasal 2020-2021, bekerjasama dengan kelompok bermain "Flamboyan" Yogyakarta yang berlokasi dekat dengan ketua pelaksana pengabdian.

Adapun beberapa profil yang menyangkut tentang kelompok bermain "Flamboyan" Cokrokusuman, Jetis, Yogyakarta yakni bahwa kelompok bermain ini memiliki SK Izin Operasional dengan nomor 00313/JT/2011, dengan NPSN (Nomor Pokok Sekolah Nasional): 69830068. Kelompok bermain ini berlokasi di Cokrokusuman, RT. 36, RW.09, Cokrokusuman, Kecamatan Jetis, Yogyakarta. Kelompok Bermain "Flamboyan" ini berada dalam kepengurusan kelurahan Cokrodiningratan, Kecamatan Jetis, kota Yogyakarta. Ketua Pembina dari KB "Famboyan" adalah Ketua RW.09 dan beberapa tokoh masyarakat di lingkungan RW. Adapun Kepala sekolah dari KB "Flamboyan" adalah Imu Supinah, yang dibantu oleh satu guru kelas yaitu Diah Kartini P. Personil yang terlibat langsung 
dalam pelaksanaan KB "Flamboyan" memiliki latar belakang pendidikan SMA sederajat.

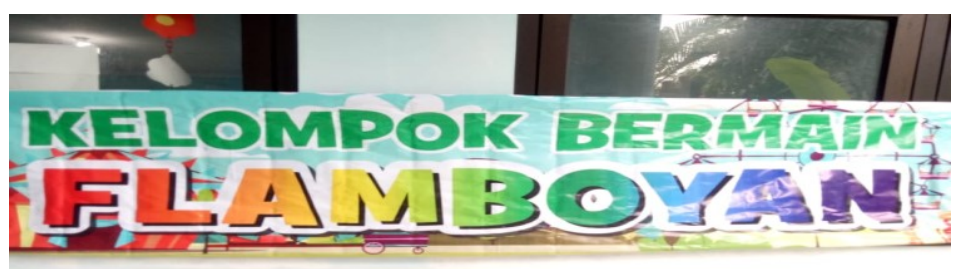

Gambar 1. Tampak depan spanduk Kelompok Bermain "Flamboyan”

Dengan semangat pengabdian yang tinggi menempatkan mereka untuk bisa mengelola KB "Flamboyan" yang bergerak dalam pendidikan anak usia dini. Dalam keseharian, guru-guru di KB "Flamboyan" telah melaksanakan kegiatan belajar mengajar dengan berpedoman pada petunjuk pelaksanaan standar yang berlaku pada Kelompok-Kelompok Belajar Usia Dini Daerah Istimewa Yogyakarta. Untuk pengembangan strategi pembelajaran anak usia dini, belum dikembangkan di KB "Flamboyan". Apalagi menghadapi masa-masa pandemi yang mengharuskan sekolah-sekolah melaksanakan pembelajaran dari jarak jauh dan tidak memperbolehkan pembelajaran tatap muka sampai masa pandemi berakhir. KB Flamboyan benar-benar belum memiliki strategi pembelajaran jarak jauh. Dengan kondisi semacam ini, bukan berarti proses pembelajaran untuk anak usia dini berhenti begitu saja. Perlu adanya langkah-langkah konkrit untuk tetap melaksanakan pembelajaran meskipun dengan metode pembelajaran jarak jauh.

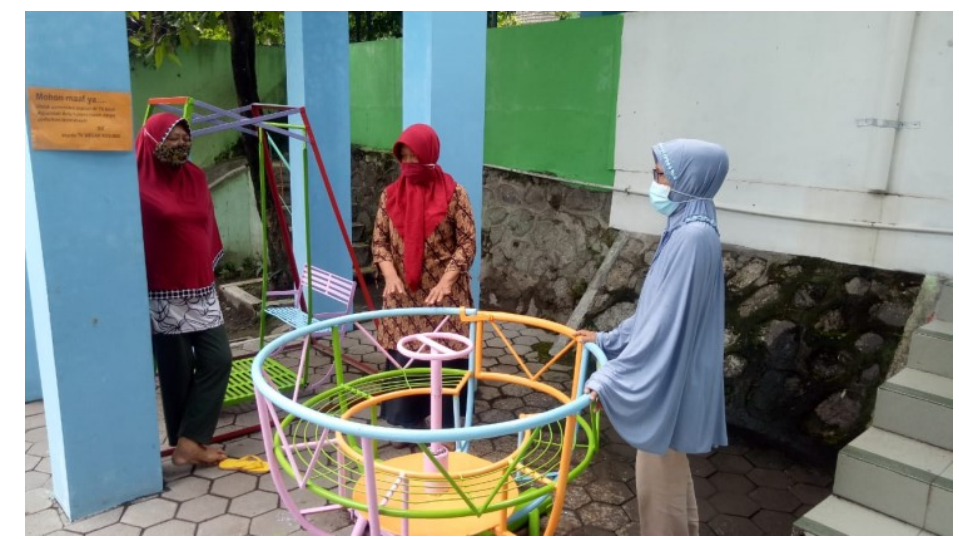

Gambar 2. Salah satu tim dosen bertemu dan berdialog dengan guru-guru KB "Flamboyan"

Adapun jumlah murid yang mengikuti pembelajaran di KB "Flamboyan" rata-rata per tahun berjumlah 11 anak. Mereka berasal dari wilayah sekitar KB "Flamboyan". Jarak terjauh dari murid yang mengikuti pembelajaran di KB "Flamboyan" sekitar 1 KM. Mereka rata-rata berasal dari keluarga ekonomi menengah ke bawah. Kesadaran orang tua yang semakin meningkat menyebabkan para orang tua yang berdomisili di sekitar KB "Flamboyan" mempercayakan pendidikan usia dini pada KB "Flamboyan". Selain untuk mempersiapkan sisi 
afektif, juga mempersiapkan keterampilan sosialisasi untuk memasukkan anak mereka ke jenjang yang lebih tinggi, yakni di TK yang selanjutnya anak sudah siap untuk meneruskan ke jenjang Sekolah Dasar.

Seperti yang telah diuraikan sebelumnya bahwa di Indonesia semenjak awal tahun 2020 hingga waktu yang belum bisa dipastikan, dilanda wabah atau pandemi covid 19. Keadaan ini yang membuat sistem belajar mengajar di sekolah-sekolah harus dilaksanakan dengan sistem pembelajaran jarak jauh (Pramana, 2020). Dalam surat edaran Kemendikbud RI tahun 2020, sekolah-sekolah tidak diperkenankan untuk membuka kelas tatap muka. Proses belajar dilaksanakan dari rumah masingmasing siswa. Aktivitas antarsiswa bervariasi yang bisa distrategikan oleh pihak sekolah masing-masing. Oleh karenanya, perlu beberapa terobosan strategi pembelajaran jarak jauh yang bisa diikuti oleh peserta didik.

Persoalan ini lebih sedikit berat karena peserta didik di jenjang anak usia dini, apalagi di kelompok bermain belum fasih dalam memakai gawai elektronik yang berbasis digital. Tidak berhenti sampai di sini, persoalan alat yang dimiliki oleh peserta didik juga menjadi kendala tersendiri. Sebagian besar peserta didik tidak memiliki perangkat telepon seluler, laptop, ataupun komputer untuk mengakses pembelajaran dari sistem dalam jaringan. Sebagai anak yang masih di bawah umur, peserta didik di KB "Flamboyan" mengandalkan gawai yang dimiliki oleh orang tua mereka. Tidak semua orang tua peserta didik KB "Flamboyan" memiliki telepon seluler yang memadai untuk mengakses pebelajaran dalam jaringan. Dari kondisi semacam ini saja, sudah tergambar betapa kompleksnya persoalan yang dihadapi guru-guru KB "Flamboyan" agar proses belajar mengajar di KB "Flamboyan" tidak terhenti.

Banyak persoalan dari pihak KB "Flamboyan" yang perlu mendapat perhatian untuk ditingkatkan dan memerlukan perbaikan-perbaikan dalam menghadapi masa pandemi covid 19 ini. Dari hasil diskusi antara pihak KB "Flamboyan" dan tim dosen, maka prioritas utama yang mendesak untuk diselesaikan bersama yakni hal srategi pembelajaran di masa pandemi yang tidak menyulitkan siswa didik. Mengingat guru adalah sebagai fasilitator, sumber belajar, dan juga sebagai pengatur jalannya proses belajar mengajar yang menyenangkan di kelas, maka diperlukan peningkatan wawasan, penyuluhan, dan pelatihan bagi guru-guru yang ada di KB "Flamboyan" tentang strategi pembelajaran jarak jauh bagi siswa prasekolah. Mengacu pada butir analisis situasi, dapat diidentifikasi permasalahan pada KB "Flmboyan" meliputi beberapa hal berikut ini: (1) Para pengajar merasa kesulitan untuk merancang strategi pembelajaran jarak jauh yang menerapkan pembelajaran non tatap muka. Mereka terbiasa menggunakan pembelajaran yang konvensional. Hal ini memerlukan pengembangan wawasan dan pelatihan tentang strategi pembelajaran jarak jauh yang tidak menyulitkan siswa dan orang tua. (2) Para guru merasa kesulitan dalam menerapkan aplikasi pembelajaran berbasis digital yang merupakan inti dari pembelajaran dalam jaringan. Oleh karenanya guru-guru perlu diperkenalkan 
sedikit tentang aplikasi yang mudah untuk dipakai dalam pembelajaran jarak jauh yang tentu saja disesuaikan dengan kemampuan anak dan orang tua. Dengan kemajuan yang sangat pesat di era digital, mau tidak mau guru-guru harus mengenal pembelajaran berbasis digital. Anak didik sedari dini diperkenalkan sedikit dengan kemajuan digital melalui pengetahuan literasi teknologi dan penggunaanya (Didiharyono \& Qur'ani, 2019). (3) Masih minimnya sarana dan prasarana pembelajaran jarak jauh, sehingga membutuhkan kreatifitas untuk dapat memanfaatkan secara maksimal dalam proses belajar-mengajar. Oleh sebab itu strategi pembelajaran dengan memanfaatkan pembelajaran blendid learning (Eriani, 2020) perlu diperkenalkan pada guru-guru KB "Flamboyan".

Dari sekian permasalahan yang ada di KB "Flamboyan", dan mengingat jangka pendek yang bisa dicapai bersama untuk meningkatkan keterampilan SDM yang ada di sana maka titik kesepakatan difokuskan pada pelatihan strategi pembelajaran jarak jauh yang aman, terjangkau bagi peserta didik, dan memiliki keefektifan yang relatif tinggi, memingat keadaan di lingkungan pebelajar masih terjadi wabah pandemi covid 19. Beberapa pertimbangan dari sekian strategi yang memungkinkan untuk diadakan dengan memperhatikan pula biaya yang menjadi beban tidak saja bagi guru-guru namun juga peserta didik, maka perlu strategi yang matang agar pembelajaran tetap berlangsung dengan baik dan aman (Oktaria, 2020). Segala bentuk pertimbangan agar pembelajaran masih tetap berlangsung meskipun dalam masa pandemi yang mengharuskan adanya PSBB (Pembatasan Sosial Berskala Besar), dan juga mempertimbangkan segi kesehatan dan keamanan bagi peserta didik yang masih tergolong usia dini, juga pertimbangan biaya adalah faktor-faktor yang menjadi perhatian utama. Dari diskusi, observasi, penyuluhan, dan pendamingan dari tim dosen untuk guru-guru KB "Flamboyan" sangat diperlukan. Salah satu tim dosen yang berdomisili berdekatan dengan KB "Flamboyan", memantau dan membimbing secara langsung untuk kemudian didiskusikan secara firtual dengan tim dosen yang lain di kampus Universitas Dr. Soetomo Surabaya.

Adapun solusi yang bisa diterapkan dalam waktu dekat dan singkat yakni, 1) Mengadakan jasa pelatihan strategi pembelajaran jarak jauh yang sesuai dengan anak didik usia dini. Jasa platihan ini diikuti oleh guru KB "Flamboyan" dan dipandu secara langsung oleh salah satu tim dosen FKIP Unitomo yang berdomisili di dekat KB "Flamboyan". 2) Mengadakan diskusi dan observasi bersama dari hasil pelatihan yang telah dilakukan dengan cara melihat dampak pada siswa yang sedang menggunakan strategi pembelajaran jarak jauh tersebut 3) Mengadakan evaluasi bersama tentang hasil akhir pelaihan. 4) Seluruh guru mampu mewujudkan pembelajaran yang menyenangkan di KB "Flamboyan", yang tentu saja keberhasilan ini didukung oleh wali murid (Koedoes, 2020). 


\section{Metode}

Berdasarkan hasil diskusi dengan KB "Flamboyan", maka prioritas permasalah yang harus diselesaikan bersama dengan KB "Flamboyan" adalah memperkenalkan seluk beluk strategi pembelajaran jarak jauh yang menyenangkan untuk anak prasekolah. Oleh sebab itu perlu adanya pelatihan dan pendampingan baik langsung maupun tidak langsung (melalui media sosial) untuk mewujudkan suasana belajar mengajar yang menyenangkan di KB "Flamboyan". Metode yang digunakan untuk pelaksanaan pengabdian di KB Flamboyan adalah dengan pelatihan dan pendampingan secara terbimbing. Salah satu tim dosen yang domisili dekat mitra pelatihan, akan memberikan pendampingan terbimbing secara tatap muka dan juga memanfaatkan media sosial sebagai cara pendampingannya.

Dalam pelaksanaan program pengabdian masyarakat mandiri ini memiliki tahapan-tahapan metode sebagaimana berikut,

1. Perencanaan Awal; pada tahap ini tim dosen yang akan melaksanakan program pengabdian masyarakat mandiri mendata ulang persoalan KB "Flamboyan" yang hendak dituju. Dari sekian permasalahan KB "Flamboyan", akhirnya tim dosen memutuskan menjalin kerjasama dengan dasar demi kemajuan bersama di bidang pendidikan. Kerjasama ini dengan dengan mempertimbangkan beberapa alasan yakni yang pertama KB "Flamboyan" adalah lembaga pendidikan yang ada di wilayah Cokrodiningratan, Jetis, Yogyakarta yang letaknya tidak jauh dari domisili salah satu dari tim dosen Universitas Dr. Soetomo. Hal sangat mendesak adalah kebutuhan akan pelaksanaan pengembangan strategi pembelajaran jarak jauh untuk anak usia dini. Para pengajarnya memerlukan banyak wawasan dan pelatihan dari para ahli strategi pembelajaran. Yang kedua, dengan sumber daya yang minim, perlu adanya pelatihan dalam segi yang lain dalam pengolahan yang efektif guna menunjang suasana belajar pembelajaran yang menyenangkan bagi siswanya.

2. Identifikasi awal dengan KB "Flamboyan"; pada tahap ini tim dosen menjajagi dengan KB "Flamboyan" tentang program pengabdian masyarakat. Identifikasi ini meliputi kerjasama selanjutnya yaitu beberapa keadaan yang perlu ditangani bersama. Dari beberapa permasalahan, dipilih prioritas yang juga cukup mendesak yang dihadapi adalah mengembangkan strategi pembelajaran yang menyenangkan di KB "Flamboyan". Oleh sebab itu tim dosen menawarkan penyuluhan dan pelatihan ke guru-guru tentang cara pengembangan strategi pembelajaran jarak jauh yang menyenangkan agar tercipta pembelajaran yang berkualitas.

3. Tahap Pelaksanaan; pada tahap ini dilaksanakan pelatihan dan pendampingan dengan metode terbimbing baik langsung maupun tidak langsung. Metode terbimbing ini dalam artian tim dosen bersedia melakukan bimbingan secara tatap muka (hanya sekali) maupun nontatap muka (yang berkomunikasi dengan memanfaatkan media sosial terutama WhatsApp) terhadap guru-guru di sana. Dalam pelatihan ini seluruh akomodasi dan perlengkapan serta persiapan 
pelatihan ditanggung bersama antara pihak tim dosen dibantu oleh pihak KB "Flamboyan". Materi yang dirujuk untuk pelatihan adalah dari sejumlah artikel jurnal, diantaranya Hutami (2020) tentang pemanfaatan WAG, mauapun dengan home visit (Suhendro, 2020). Adapun yang dilatihkan adalah pengembangan dari bahan ajar tersebut. Modul atau bahan ajar tersebut bisa dipakai para guru di sana untuk membuka wawasan baru tentang strategi pembelajaran untuk anak usia dini. Pada tahap ini terbagi dalam dua kali penyuluhan dan pelatihan serta observasi hasil dan evaluasi, pendampingan (baik secara tatap muka atau nontatap muka) dengan durasi waktu per tatap muka kurang dari satu jam dan tetap menjaga jarak dan memakai masker, hal ini mengingat masih dalam masa antisipasi penyebaran viruz Covid 19.

4. Tahap Evaluasi Pelaksanaan; pada tahap ini dilaksanakan evaluasi yang dilakukan oleh tim dosen dibantu dengan KB "Flamboyan". Cara mengevaluasi antara pihak guru dan tim dosen dilakukan secara tidak langsung, yakni memanfaatkan media sosial. Tahapan ini dilakukan dengan cara membuka diskusi bagi pihak guru dan tim dosen di grup WhatsApp dan juga secara langsung melalui salah satu perwakilan tim dosen yang berdekatan dengan lokasi KB Flamboyan.

\section{Hasil dan Pembahasan}

Pada penyuluhan dan pelatihan pertama dilakukan penjabaran tentang apa dan bagaimana strategi pembelajaran untuk anak usia dini. Beberapa referensi yang digunakan untuk materi pada pelatihan ini yakni dari Huda (2020), Desmita (2012), Majid (2010), Khatijah (2015), dan Hamdayana (2014). Ada jurnal penelitian menjadi referensi untuk dijadikan model pelaksanaan metode belajar jarak jauh dengan kombinasi pembelajaran daring dan luring. Referensi tersebut diambil dari penelitian Suhendro (2020), Ahsani (2020), Hewi (2020), Pramana (2020), Satrianingrum (2020) yang memungkinkan untuk diterapkan sebagai pegangan dalam pelaksanaan pembelajaran jarak jauh untuk KB "Flamboyan".

Dalam penyuluhan pertama yang dilakukan secara tatap muka namun tetap melaksanakan protokol kesehatan, beberapa yang bisa dikembangkan adalah perancangan strategi pembelajaran tentang pembelajaran jarak jauh dengan kombinasi daring (dalam jaringan) dan luring (luar jaringan). Pembelajaran jarak jauh ini mau tidak mau meminta peran aktif dari orang tua atau wali murid peserta didik. Komunikasi yang biasa dipakai untuk informasi dan pembelajaran menggunakan aplikasi grup WhatsApp. 


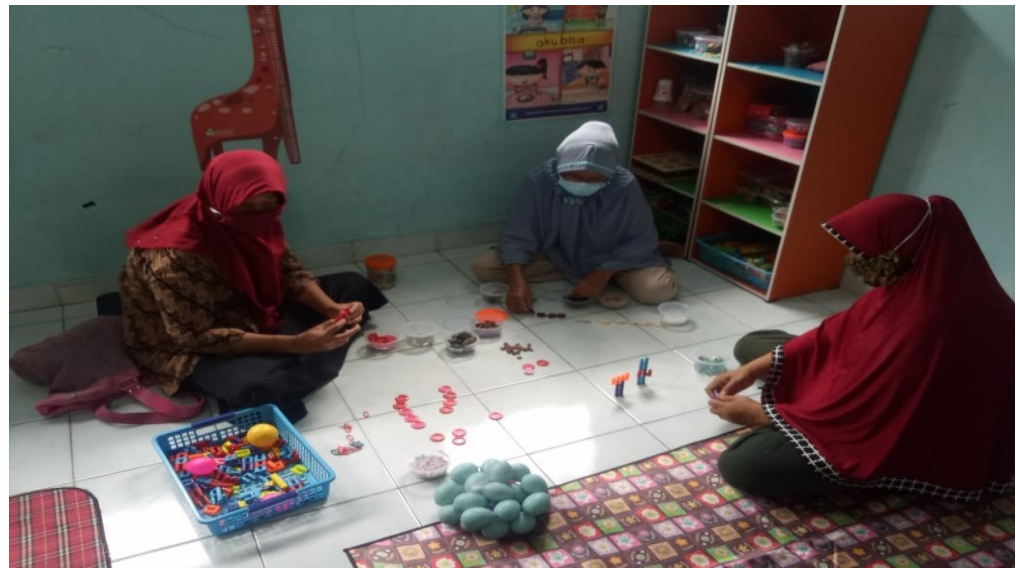

Gambar 3. Mendata media pembelajaran yang memungkinkan bisa dipinjamkan ke murid untuk PJJ

Pembelajaran daring memanfaatkan media sosial grup WhatsApp. Grup WA tidak sekedar untuk alat komunikasi antara wali murid dan guru, namun juga untuk menyampaikan materi pembelajaran dan tugas-tugas. Hal ini ditempuh karena peserta didik menggunakan telepon seluler milik orang tua. Pertimbangan berikutnya adalah bahwa kuota data yang paling murah adalah memanfaatkan grup WA. Hanya sekali menggunakan pembelajaran google meet, tidak lama, dan peserta didik yang didampingi orang tua juga tidak banyak yang mengikuti. Situasi ini disebabkan karena banyak orang tua dari para peserta didik yang bekerja, sehingga telepon seluler juga dipakai untuk bekerja.

Tim dosen juga menganjurkan pada guru untuk senantiasa berkomunikasi dengan sabar kepada para orang tua siswa yang beagam karakteristiknya. Di selasela penyuluhan, tim dosen berpesan agar para guru menyampaikan pada anakanaknya untuk memahami mengapa sekolah atau belajar di rumah saja, mengapa keluar rumah harus menggunakan masker, kenapa tidak bisa bermain di luar rumah dengan menggunakan metode dialog (percapakan /diskusi) dan keteladanan.

Tim dosen mencoba memberi contoh beberapa tugas yang bisa dilakukan oleh siswa dan orang tua di rumah, yaitu pembelajaran kepekaan dan pengenalan bau atau aroma. Pelatihan mengenali aroma atau bau, para guru dilatihkan untuk memanfaatkan botol plastik kecil bekas yang diisi dengan aroma tertentu. Dalam mengenali aroma ini, dibuatlah pasangan aromanya, agar tiap siswa mampu melatih indera penciumannya. Ada aroma bunga melati, minyak kayu putih, cengkih, kapus barus dan lain-lain yang tersedia di rumah. Dengan cara menaruh beberapa macam bahan di dalam kain, atau kertas tisu, dan sebagian dibungkus atau dioleskan di kain kasa. Siswa disuruh menaruh dengan tepat di sesuai dengan pasangan aromanya.

Tugas-tugas siswa yang di bagikan melalui grup WA, tentunya menuntut evaluasi bersama. Oleh karenanya pada setiap tugas, diwajibkan untuk mengirim foto hasil unjuk kerja siswa ke grup, sehingga dapat dilakukan evaluasi bersama dengan pihak para orang tua. Metode pembelajaran luar jaringan (luring) dilakukan dengan datang ke rumah siswa untuk memberikan materi pembelajaran dengan menerapkan aspek afektif kognitif dan motorik anak. Guru memberikan cetakan 
tugas-tugas yang nantinya dikumpulkan kepada pendidik pada akhir bulan atau sesuai dengan jadwal yang telah ditentukan bersama. Cetakan tugas ini diserahkan pada orang tua untuk dikerjakan anak mereka sebagai potoforlio ketika pembelajaran menulis, menggambar, menghitung, dan beberapa pembelajaran motorik halus. Penyerahan cetakan tugas tetap memperhatikan protokol kesehatan dengan mengenakan masker. Konsultasi dan dialog guru dengan orang tua juga harus menjaga jarak. Dengan metode home visit, guru dapat mendorong orang tua untuk ikut memotivasi anak agar tetap belajar. Pemberitahuan materi sebelum guru melakukan kunjungan menumbuhkan sikap orang tua untuk memperhatikan kebutuhan anak. Kehadiran guru di rumah murid dapat menjadi pemicu semangat anak-anak untuk tetap belajar.

Dalam proses evaluasi bersama antara guru-guru dan tim dosen, respon orang tua siswa yang terjaring dalam wawancara guru mengungkapkan guru sudah sangat kreatif dalam proses pembelajarannya, karena setiap pertemuan guru dan orang tua selalu memotivasi anak agar anak giat belajar, kemudian mengarahkan anak untuk aktif dalam proses pembelajaran.

Ada yang masih dalam persoalan pembelajaran jarak jauh yakni kegiatan pembelajaran di luar sekolah tentu memerlukan tambahan dalam anggaran. Hal tersebut tampaknya perlu untuk dipikirkan oleh KB "Flamboyan" beserta stake holder yang akan melaksanakan program home visit kedepan. Ada beberapa aspek yang berubah seperti bekal guru, transportasi, resiko di jalan adalah hal-hal yang harus dijadikan pertimbangan sebelum melaksanakan program lebih jauh mengingat jarak rumah siswa yang tidak saling berdekatan. Bagaimanapun pembelajaran luar jaringan yang memakai metode home visit, memerlukan energi, biaya, dan waktu yang relatif besar untuk dikeluarkan.

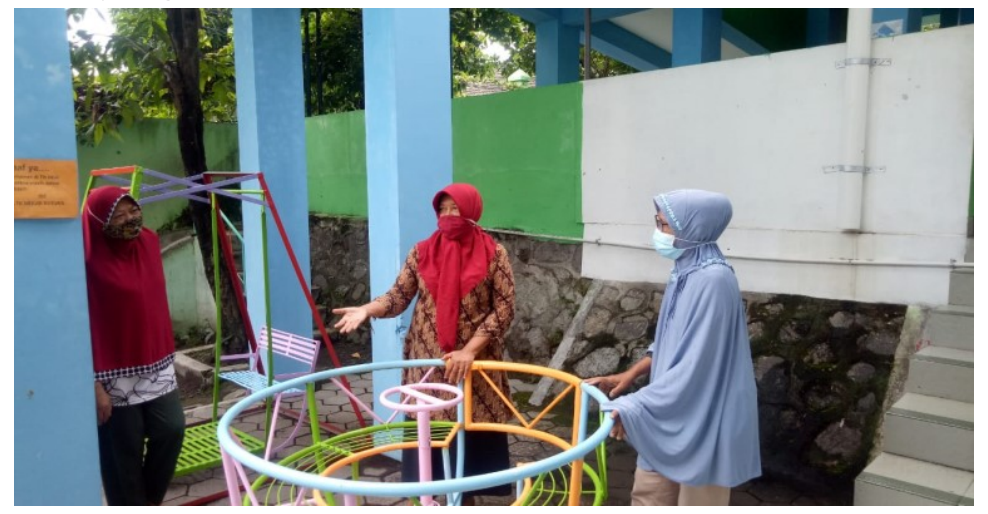

Gambar 5. Tim dosen memberi saran agar permainan outdoor dikunci

Program Pengabdian Masyarakat ini memiliki target luaran untuk meningkatkan kualitas SDM dan keterampilan guru dalam melaksanakan pembelajaran jarak jauh di masa PSBB dengan pengadaan strategi pembelajaran daring dan luring yang menyenangkan dan berguna bagi siswa. Dari hasil evaluasi, yang dilaksanakan antara tim dosen dan KB "Flamboyan", ada peningkatan 
keterampilan guru dalam proses pelaksanaan pembuatan media belajar. Hal ini tampak dalam bagan berikut,

Tabel 1. Pencapaian Kegiatan Pelatihan dan Penyuluhan

\begin{tabular}{|c|c|c|c|}
\hline No & Aspek & $\begin{array}{c}\text { Sebelum } \\
\text { Penyuluhan }\end{array}$ & Sesudah Penyuluhan \\
\hline $\mathbf{1}$ & $\begin{array}{l}\text { Konsep strategi } \\
\text { pembelajaran } \\
\text { jarak jauh }\end{array}$ & Belum ada bayangan & $\begin{array}{l}\text { Sudah mampu merumuskan } \\
\text { bahkan melaksanakan konsep } \\
\text { strategi belajar jarak jauh untuk } \\
\text { anak prasekolah di masa } \\
\text { pandemi yang mengharuskan } \\
\text { berlakunya PSBB. }\end{array}$ \\
\hline 2 & $\begin{array}{c}\text { Perumusan } \\
\text { solusi strategi } \\
\text { pembelajaran } \\
\text { luring } \\
\text { divariasikan } \\
\text { dengan daring. }\end{array}$ & $\begin{array}{l}\text { Belum } \\
\text { memb }\end{array}$ & $\begin{array}{l}\text { Sudah mampu melaksanakan } \\
\text { pembelajaran luring dengan } \\
\text { home visit beserta portofolio } \\
\text { tugas-tugas siswa yang harus } \\
\text { diserahkan sebulan sekali. }\end{array}$ \\
\hline 3 & $\begin{array}{l}\text { Menggunakan } \\
\text { media belajar } \\
\text { yang sesuai } \\
\text { dengan } \\
\text { pembelajaran } \\
\text { jarak jauh }\end{array}$ & $\begin{array}{l}\text { Hanya tugas untuk } \\
\text { keseharian siswa } \\
\text { yang sederhana }\end{array}$ & $\begin{array}{l}\text { Sudah dilakukan dan lebih } \\
\text { bervariasi, meminjamkan media } \\
\text { pembelajaran pada siswa } \\
\text { dengan jangka waktu tertentu, } \\
\text { hingga aturan jadwal } \\
\text { pengembalian dan cara } \\
\text { pengembalian } \\
\text { pembelajaran pada guru. }\end{array}$ \\
\hline 4 & $\begin{array}{l}\text { Hasil langsung } \\
\text { ke siswa }\end{array}$ & $\begin{array}{c}\text { Siswa tampak biasa } \\
\text { saja }\end{array}$ & $\begin{array}{l}\text { Siswa lebih antusias belajar dari } \\
\text { rumah, terpantau dari home visit } \\
\text { yang berlangsung secara } \\
\text { bergiliran. }\end{array}$ \\
\hline
\end{tabular}

Adapun luaran yang sudah berhasil dicapai dalam rangkaian kegiatan keseluruhan program pengabdian masyarakat mandiri terlihat pada tabel berikut,

Tabel 2. Luaran dan Capaian

\begin{tabular}{lcl}
\hline No & \multicolumn{1}{c}{ Luaran } & \multicolumn{1}{c}{ Capaian } \\
\hline $\mathbf{1}$ & Jasa Pelatihan berupa penyuluhan dan \\
pendampingan & $100 \%$, dengan tatap muka \\
& & $\begin{array}{l}\text { (wakil dosen yang dekat } \\
\text { dengan lokasi mitra) dan tatap } \\
\text { maya/ daring (dengan tim } \\
\text { dosen) }\end{array}$ \\
\hline $\mathbf{2}$ & $\begin{array}{l}75 \% \text { (terlaksananya program } \\
\text { home visit, dan pembelajaran }\end{array}$ \\
& jarak jauh, terkendala karena \\
& biaya operasional) \\
\hline $\mathbf{3}$ & Peningkatan kualitas SDM & $\begin{array}{l}100 \%, \text { berdasar observasi } \\
\text { kualitas guru (saat menghadapi } \\
\text { pandemi). }\end{array}$ \\
\hline
\end{tabular}


Produk yang berupa hasil kerja guru juga mencapai ketuntasan dalam menghasilkan produk dan kreatifitasnya. Masing-masing guru telah dapat membuat strategi pembelajaran jarak jauh sesuai dengan tingkat keamanan dan kenyamanan siswa. Guru telah banyak berkreasi dalam hal bentuk mengolah pembelajaran daring dan luring dengan home visit dan dengan memanfaatkan media sosial sebagai media komunikasi antara guru, orang tua murid dan para muridnya. Jika dinilai pada segi peningkatan produk, maka masih berjalan $75 \%$ karena memang terkendala biaya. Pelaksanaan home visit bagi guru dirasa memberatkan baik dari segi waktu, tenaga, dan biaya. Dari kendala ini ada beberapa siswa yang tidak dikunjungi secara langsung, namun bisa dilaksanakan dengan cara orang tua murid saling membagi kabar, informasi, dan tugas untuk murid yang lain. Untuk pengumpulan tugas berupa portofolio, terkadang memerlukan orang tua yang bisa dititipi untuk siswa yang lain. Jadi antara orang tua murid terjalin kerjasama berupa penitipan tugas dari sekolah, dan pengupulan hasil tugas untuk diserahkan ke pihak sekolah.

\section{Kesimpulan}

Pengembangan strategi pembelajaran sangat diperlukan dalam proses belajar mengajar dan harus mengikuti perkembangan zaman dan menghadapi berbagai situasi. Strategi pembelajaran jarak jauh harus dijalankan karena pemerintah telah mencanangkan PSBB (Pembatasan Sosial Berskala Besar) yang mengharuskan sekolah-sekolah ditutup sementara untuk menghindari kerumunnan hingga masa pandemic covid 19 berakhir. Diperlukan pengembangan pembelajaran jarak jauh yang cukup efektif dan bermanfaat maksimal bagi para siswa, yaitu dengan pembelajaran daring dan luring. Perlu kerjasama yang aktif antara orang tua siswa dan guru untuk bisa memahamkan pada anak-anak tentang mengapa sekolah di rumah, mengapa keluar rumah harus menggunakan masker, kenapa tidak bisa bermain di luar rumah menggunakan metode dialog (percapakan /diskusi) dan keteladanan. Persoalan biaya yang tidak sedikit dalam melaksanakan pembelajaran jarak jauh memang memerlukan solusi lebih lanjut, sebab pada masa pandemi semua terkena dampaknya terutama dalam hal pembiayaan. Oleh karenanya, untuk permasalahan pembiayaan proses pembelajaran pada masa pandemi, perlu juga ada kepedulian dari pemerintah daerah dan tanpa kecuali menjadi tanggung jawab bersama antara stake-holder, pihak sekolah, dan wali murid.

\section{Ucapan Terimakasih (Optional)}

Kegiatan pengabdian di TK Flamboyan, tentunya tidak terlepas dari beberaapa pihak dalam perwujudannya. Oleh karena itu ucapan terima kasih, ditujukan kepada: 1) Rektor Universitas Dr. Soetomo Surabaya, yang sealu memberikan dukungan penuh pada para dosen dalam melaksanakan kegiatan Tri Dharma Perguruan Tinggi; 2) Dekan Fakultas Keguruan dan Ilmu Pendidikan, Dr. Hetty Purnamasari, M.Pd., yang telah memberikan stimulus dan dukungan positif 
untuk para dosen yang melaksanakan Tri Dharma Perguruan Tinggi; (3) Kepala Sekolah TK Flamboyan beserta seluruh guru yang telah percaya untuk kerja sama dengan tim dosen dari FKIP, Universitas Dr. Soetomo Surabaya serta telah memberi dukungan baik moril maupun materil selama proses pelatihan berlangsung, serta mengikuti setiap sesi pendampingan; (4) Rekan-rekan dosen FKIP, yang selalu saling mengingatkan dan mendukung segi yang positif; (5) Mahasiswa yang turut membantu kami pelaksanaan mulai pada tahap awal hingga akhir pelatihan.

\section{Daftar Pustaka}

Ahsani, ELF. (2020). Strategi Orang Tua dalam Mengajar dan Mendidik Anak dalam Pembelajaran at the Home Masa Pandemi Covid-19. Al-Athfal: Jurnal Kajian Perkembangan Anak Dan Manajemen Pendidikan Anak Usia Dini. 3(1), 37-46.

Astuti, I. Y., \& Harun. (2020). Tantangan Guru dan Orang Tua dalam Kegiatan Belajar dari Rumah Anak Usia Dini pada Masa Pandemi Covid-19. Jurnal Obsesi : Jurnal Pendidikan Anak Usia Dini. 5(2), 1454-1463.

Didiharyono, D., \& Qur'ani, B. (2019). Increasing Community Knowledge through the Literacy Movement. To Maega: Jurnal Pengabdian Masyarakat, 2(1), 1724.

Eriani, Eva., \& Emilia.Reni. (2020). Blended Learning: Kombinasi Belajar Untuk Anak Usia Dini di Tengah Pandemi. Mitra Ash-Shibyan: Jurnal Pendidikan dan Konseling. 3(1),11-21.

Hamdayama, Jumanta. 2014. Model dan Metode Pembelajaran Kreatif dan Berkarakter. Bogor: Ghalia Indonesia.

Hewi, L., \& Asnawati, L. (2020). Strategi Pendidik Anak Usia Dini Era Covid-19 dalam Menumbuhkan Kemampuan Berfikir Logis. Jurnal Obsesi: Jurnal Pendidikan Anak Usia Dini. 5(1),158-167.

Huda, N., Mardiana, N., \& Imayah, I. (2020). Strategi Pembelajaran bagi Guru di Lembaga Pendidikan Islam Anak Sholeh Pepelegi, Sidoarjo. To Maega: Jurnal Pengabdian Masyarakat, 3(2), 111-121.

Hutami, M. S., \& Nugraheni, A. S. (2020). Metode Pembelajaran Melalui Whatsapp Group Sebagai Antisipasi Penyebaran Covid-19 pada AUD di TK ABA Kleco Kotagede. Paudia: Jurnal Penelitian Dalam Bidang Pendidikan Anak Usia Dini. 9(1), 126130.

Khadijah. (2015). Strategi pembelajaran Anak Usia Dini. Medan: Perdana Publishing

Koedoes, Yuni A., dkk. (2020). Solusi Pembelajaran Anak Usia Dini pada Masa Pandemi Covid-19. Jurnal Pengabdian Masyarakat Terapan. 2(2), 87-92.

Majid, Abdul. (2010). Strategi pembelajaran. Bandung: Rosda Karya.

Menteri Pendidikan dan Kebudayaan Republik Indonesia. (2020). Surat Edaran Nomor 4 Tahun 2020 Tentang Pelaksanaan Kebijakan Pendidikan Dalam Masa Darurat Penyebaran Coronavirus Disease (COVID-19) Republik Indonesia. https://pusdiklat.kemdikbud.go.id/surat-edaran-mendikbud-no-4tahun-2020-tentang-pelaksanaan-kebijakan-pendidikan-dalam-masa-daruratpenyebaran-corona-virus-disease-covid-1-9/ 
Oktaria, R., \& Putra, P. (2020). Pendidikan Anak dalam Keluarga sebagai Strategi Pendidikan Anak Usia Dini saat Pandemi Covid-19. Jurnal Ilmiah PESONA PAUD. 7(1), 41-51.

Pramana, Cipta. (2020). Pembelajaran Pendidikan Anak Usia Dini (PAUD) di Masa Pandemi Covid-19. Indonesian Journal of Early Childhood. 2(2), 115-123.

Putri, E. A., Hariyanto, E., Sunaryo, T., \& Hisyam, C. J. (2020). Pelatihan Peningkatan Kompetensi Mengajar Bagi Petugas Lembaga Pembinaan Khusus Anak (LPKA) Tangerang, Banten. To Maega $\mid$ Jurnal Pengabdian Masyarakat. 3(1),36-46.

Sari, D. Y., \& Rahma, A. (2019). Meningkatkan Pemahaman Orang Tua dalam Menstimulasi Perkembangan Anak dengan Pendekatan Steam melalui Program Home Visit. Jurnal Tunas Siliwangi. 5(2), 93-105.

Satrianingrum, A. P., \& Prasetyo, I. (2020). Persepsi Guru Dampak Pandemi Covid-19 terhadap Pelaksanaan Pembelajaran Daring di PAUD. Jurnal Obsesi: Jurnal Pendidikan Anak Usia Dini. 5(1), 633-640.

Suhendro, Eko. (2020). Strategi Pembelajaran Pendidikan Anak Usia Dini di Masa Pandemi Covid-19. Golden Age, Jurnal Ilmiah Tumbuh Kembang Anak Usia Dini. 5(3), 133-140. 